\title{
Genesis of podiform chromitites - a review of models
}

\author{
Pavel Borisovich SHIRYAEV ${ }^{* *}$, \\ Nadezhda Vladimirovna VAKHRUSHEVA ${ }^{1,2^{2 *}}$
}

${ }^{1}$ The Zavaritsky Institute of Geology and Geochemistry of the Ural Branch of RAS, Ekaterinburg

${ }^{2}$ Ural State Mining University, Ekaterinburg, Russia

\begin{abstract}
Relevance of the work. Research aimed at identification of genesis of chromium ores in alpine-type hyperbasites has been conducted by scientists (geologists, petrologists and geochemists) around the world for more than a century. Nevertheless, the issue of their origin remains debatable to this day.

The purpose of the work is to highlight the main stages of the development of scientific ideas about the genesis of chromian mineralization in alpinotype hyperbasites; to present and summarize the main, most significant and innovative scientific ideas of Russian and foreign experts who have been involved in this issue.

Results. The evolution of scientific views on the genesis of chromic mineralization from the second half of the 19th century is traced. In Russia and abroad, its main stages are highlighted. Throughout this period, some ideas dominated that link the formation of concentrations of ore-forming chrome-spinels with its crystallization from magmatic melt. Major discoveries in earth sciences - the emergence of plate tectonics, the discovery of UHP minerals in chromite-bearing ultrabasites, intensified the scientific search and led to the emergence of alternative models that consider chromitites as products of metasomatism or metamorphism. Particular attention is paid to the results of research by Russian experts, whose scientific contribution to the development of ideas about the genesis of chromium ores is very large and at the same time, from our point of view, underestimated.

This work is intended for geologists, petrologists, and experts in the geology of ore deposits dealing with ultramafic, chromic ores, and ophiolite complexes in general.
\end{abstract}

Keywords: chromitites, alpinotype ultramafites, ophiolites, formation models, genesis, research review.

Early stage

At the end of the XIX and the beginning of the XX centuries, an active industrial production of alloyed steels and ferroalloys began. Metallurgists became interested in chromic iron, which was previously used mainly in the manufacture of paint pigments. An active study of chromite-bearing massifs and chromium ores (chromite) began.

The earliest models of the formation of chromium ores widespread at the end of the 19th century considered them as products of secondary changes in peridotites enriched in chromium $[1,2]$. The authors suggested that the formation of chromite deposits is associated with serpentinization of peridotites. Serpentinization was considered a hypergenic process. Iron and chromium released from silicates during serpentinization enter into reaction leading to the formation of ore chromium spinel.

Johan Herman Lie Vogt [3] in his work, using no.rway deposits as an example, showed that chromitites can occur in completely unchanged peridotites, and for the first time it was suggested that magmatic segregation is the only mechanism of their formation. Chrome spinel being the most idiomorphic phase, crystallizes from the melt first.

In subsequent years, the hypothesis of the formation of chromitites as a result of crystallization from magma was basic and generally accepted. This view was held by Waldemar Lindgren, one of the founders of economic geology, in his authoritative monograph "Ore deposits" [4]. Appeared publications supplemented and detailed the magmatic model. In the 20 s of the twentieth century, J. E. Sperr et al [5] noted that the ore bodies of chromitites are often vein-shaped. Based on this observation, they suggested that chromitites are formed in the late stages of magma differentiation and fills fractures in solid host rocks.

The foundations of experimental magmatic petrology were laid in the works of no.rman Levy Bowen, one of the most famous petrologists of 20th century. He also dealt with the formation of chromitites. From his point of view [6], during direct crystallization of chromitite from melt (similarly to that proposed by Vogt), in order to obtain concentrations of chromium spinels it is necessary to re-melt mineral crystals that have previously crystallized from the melt. In this case, spinel can be enriched with its refractory components, in particular chrome. Such a process requires maintaining high temperatures in the system for a long time interval, which, as the author points out, is difficult to implement. According to the model proposed by Bowen, spinel can be formed by the reaction of the melt having a composition close to basalt with the association of anorthite and olivine. The aluminous spinel formed in this way is stable in the absence of a reverse reaction, which can occur when the temperature drops. The reverse reaction causes the appearance of the main plagioclase with olivine and high-Cr spinel. In the 
further course of this reaction, spinel can be converted into a noticeably chromium clinopyroxene.

The extraordinary view of Aleksandr Karpinsky on the genesis of the indigenous deposits of platinum and chromium of the Ural type deserves attention [7]. From his point of view, chromitites are a post-intrusive igneous product. Chromites initially accumulate and harden at the base of the peridotite massif, and then, due to explosive processes, when accumulated volatiles are separated, they are carried out to its upper horizons, like diamonds or eclogite rocks in kimberlite pipes. The vein-like, pillar-shaped forms of ore bodies were considered by the author as the result of the mechanical introduction of chromite. no.dular chromites, according to A. P. Karpinsky, are pebbles formed at high temperature and for a short period of time during the process of mechanical movement of ore substance.

However, the magmatic hypothesis of the origin of chromium ores was more widespread among local researchers. For example, Anatoliy Grigor'evich Betekhtin adhered to this theory. He began his career on the expedition of Aleksandr Nikolaevich Zavaritsky to the Rai-Iz massif. According to his ideas [8], chromite deposits are formed in the magma chamber at different stages of its evolution. The main mass of chromium is concentrated in accessory chrome-spinels, which crystallize simultaneously or slightly earlier than olivine. Part of chromium is bound by volatiles and forms stable compounds during the magmatic process and decaying at a late stage with the formation of industrial deposits of chromium ores.

Gleb Aleksandrovich Sokolov, an explorer of chromite and iron ore deposits of the USSR, had similar views. One of his monographs is devoted to the study of the composition, crystallization conditions, and patterns of distribution of Ural chromites. According to the author, industrial deposits of chromite ores are the result of crystallization of residual melts of ultrabasic magmas, which are separated by individual closed areas in ultrabasic intrusions ending their crystallization [9]. In his works, the author analyzed the geological structure of ore objects, their mineralogy and chemistry of ore-forming chrome spinels, and the structure and texture of chrome ores.

The first genetic classification of chromitie deposits was proposed by Edward Sampson [10]. Summing up the existing information and the advanced scientific views of his time, Sampson identified 3 types of chromitite deposits: (1) igneous deposits in which chromite is formed before olivine; (2) late-magmatic, in which chromite crystallizes together with the most recent silicates (Bushveld, Great Dyke, Stillwater); (3) hydrothermal, which, in his opinion, are most widespread (Woods Mine (Pennsylvania), Hell Creek (Montana, USA), Old Dominion (Quebec, Canada)) In addition, the author suggests the existence of a fourth group, in which chrome spinel is associated with diopside or tremolite. However, due to the fact that no industrial deposits of this type were discovered at that time, he suggests referring them to the third group of his classification. The reason for the introduction of the fourth group was the article by Clarence Ross [11], in which he suggested the formation of chromite veins in dunites of no.rth Carolina due to the removal of components from the host rocks under the influence of hydrothermal fluids. In host dunites, anthophyllite, talc, actinolite, kemmererit are developed, and ores contain diopside and actinolite. In a later work [12], the author does not agree with his opponents who attribute these minerals to products of regional dynamic metamorphism [13], but insists on their hydrothermal origin.

In 1946, the term "podiform chromitites" first appeared in the literature. It was introduced by Francis Wells [14] in his work devoted to geology, structural features, and composition of ores of chromite deposits in no.rthern California. The term emphasized that the shape of the ore bodies developed within the studied objects is not stratified (typical of stratiform deposits), but lenticular.

The results of chromitite research, obtained in the first half of the 20th century, are summarized by Walter Petrascheck 's work "Genetic types of chromite deposits and their exploration" [15]. The author highlights the following stages of chromitites formation:

1. Early magmatic crystallization: a) disseminated crystallization (accessory spinel and low-grade impregnated ore are formed); b) segregation of crystals into chromite beds and streaky mass; c) injections of previously separated ore segregations into higher layers of the host rocks.

2. Late magmatic buildups: a) liquid segregation - nodular ores as a rough ore-silicate emulsion; b) injecting liquid segregation with the formation of ore veins.

I. F. Forester and S. Grafenauer [16] also distinguish between early and late magmatic types of chromite deposits. The second one, according to the authors, is the most important. Ores are formed from chromite ore magma enriched with volatile components. In the type there are two subtypes: 1) bodies displaced from the place of separation of ore magma; 2 ) bodies formed due to the introduction of ore magma into hardened parent rocks.

Extensive material on the geology, mineralogy, and geochemistry of chromite-bearing ultrabasites was obtained by local researchers in the study of the unique Kempirsay massif containing a super-large chrome ore deposit Almaz-Zhemchuzhina. The results of long-term studies of the geology and chromic mineralization of the Kempirsay deposits formed the basis of the monograph of Nikolay Vasilevich Pavlov "Chromites of the Kempirsay Pluton" [17]. The formation of chromium mineralization of the massif, according to the author, was due to the direct crystallization of chrome spinel from silicate ultrabasic melt in the magma chamber. no.dular ores, in his opinion, occur during the segregation of ore-silicate melt.

Svetlana Vladimirovna Moskaleva had a different view at the genesis of Kempirsaya chromitites [18]. In her opinion, the formation of chrome ores in the Kempirsay massif occurred metasomatically due to olivization of harzburgites. The source of chromium was enstatite, which contains up to $0.7 \% \mathrm{Cr}_{2} \mathrm{O}_{3}$. Subsequent progressive metamorphism led to the "dissemination" of chrome spinel and a deterioration in the quality of chromitites.

Until the 60s of the 20th century, when discussing the genesis of chrome ores, researchers did not divide them into podiform and statiform. In his work Thomas Thayer [19] distinguished these concepts. Podiform chromitites with typical structures and forms of ore bodies, according to his ideas, are formed when differentiated (stratiform) bodies move in the form of autoliths in the magmatic flow; these are relics of primary ores - products of magmatic differentiation.

The emergence of plate tectonics paradigm

A new stage in the evolution of ideas about the genesis of chromium ores was associated with the emergence and 
formation of the concept of plate tectonics in the mid 60-ies of the twentieth century. It is important to note that Petr Yakovlevich Yarosh, Evgeniy Pavlovich Tsaritsyn, Svyatoslav Nestorovich Ivanov, employees of the Institute of geology (Ural Scientific Center of the USSR Academy of Sciences), were among the first researchers to deal with the metallogeny of ultramafic rocks based on the new global tectonics. At this stage, the ideas about the origin of alpinotype peridotites are fundamentally changed. They are considered as a product of depletion of the mantle as a result of partial melting that occurs during adiabatic decompression in spreading zones. The rocks of the dunite-harzburgite complex cease to be interpreted as crystallization products of ultrabasic magma. There is a basis for the development of non-magmatic hypotheses of the formation of chromitites.

The paper [20] summarizes the views of S. N. Ivanov and P. Ya. Yarosh on the mechanism of chromium ores formation. The original olivine in mantle contains cr-spinel in the form of a solid solution (published in works [21, 22]). The transition of ultramafic rocks to conditions different from mantle ones with lower P and T leads to solid-solution breakdown. The precipitated chrome spinel phase, when the rock enters the active zones (zones of deformation, permeability, and treatment with hot fluids) migrates from olivine grains and forms independent clusters.

The work of Aleksandr Sergeevich Varlakov [23] suggests that the olivine-chromite substance had a gel-like state of aggregation before crystallization. This explained the relatively uniform distribution of ore-forming minerals in the olivine-chromite aggregate. Chromites, according to the author, were of a metasomatic origin, chromium was released during the "olivization of harzburgites» and was transferred by a metasomatic agent as a gel-like substance. Localization of chromite mineralization is determined by two main structural factors: tectonic and contractional. It is important to note that the actual data on the tectonic control of mineralization (for example, [24, etc.]) do not find explanation in any of the currently popular ore formation models.

In another work [25], ideas are presented about the possibility of the formation of chromium ore deposits under the influence of cavitation. As a result of decompression, a cavitation pocket is formed in the water-saturated rock, which expands rapidly. Such expansion leads to adiabatic cooling of the gases filling it and a decrease in their pressure. When the pressure of the internal gases of the pocket drops to the value of the external value, its rapid compression occurs with an adiabatic increase in the PT parameters, i. e. the cavitation process is being realized. The greatest amounts of movement during the interaction of the pocket front with rock matter will be linked with heavy chemical elements. Since the process is centripetal, heavy atoms should concentrate on an ever-shrinking volume and form ore clusters.

Studies of foreign scientists of that time were still conducted within the framework of the magmatic hypothesis. Studying the chromite mineralization of New Caledonia, Daniel Kassard et al. [26] identified three types of bodies of podiform chromitites: 1 . Concordant chromitites occurring subparallel to folding in peridotites; orientation of the long axes of pyroxene crystals is subparallel to the elongation of ore bodies. 2. Sub-concordant chromitites occurring with a small $\left(10-25^{\circ}\right)$ angular nonconformity with respect to banding in harzburgites. 3 . Discordant chromitites having a complex, arbitrary shape and discordant folding and banding of the host rocks. The discordant ore bodies are the earliest ones according to the author. They represent the channels through which magma penetrated into the magma chamber formed under the zones of oceanic spreading. Concordant and sub-concordant bodies are the discordant ones but displaced with a lenticular shape during the deformation of harzburgites by force of the plastic flow.

Explaining the mechanism of formation of discordant ore bodies, Cassard refers to the work of Bernard Lago [27]. The formation of chromitites, according to Lago, occurred in a relatively large cavity (100-200 $\mathrm{m}$ long and 2-5 m wide) inside the mantle diapir. This cavity was filled with melt. The temperature difference between the rising melt and the wall of the fracture caused strong convection. In the convection cell, the chromite grains were separated from the main portion of the melt, formed intergrowths, grain clusters, and nodules. At the boundary of the upward and convective flows, the interaction of the melts occurred, which led to the replenishment of the amount of chromium consumed during crystallization of chromite in the medium. This concept was subsequently adopted and finalized by Mark Leblanc [28].

In 1994-1996, under the influence of papers by B. Lago and M. Leblanc, a model of chromitites formation under the conditions of the melt seeping through the peridotite layer with the surrounding rock was proposed in [29, 30, etc.]. The petrological basis of the model is the work of Thomas Irvine [31]. According to this work, stratiform intrusion chromitites crystallize as a result of mixing a chromium-enriched melt of an intermediate picrite-tholeiitic composition with a similar composition but $\mathrm{SiO}_{2}$-rich one. In the case of podiform peridotites, the formation of chromitites occurs according to the following scheme [29]. The host peridotite reacts with leaking melt (melt A, Fig. 1), which leads to the formation of dunite and melt (melt B, Fig. 1), which is relatively enriched in $\mathrm{SiO}_{2}$. Mixing the $\mathrm{SiO}_{2}$-enriched melt and the next portion of primitive magma (with olivine-chromite cotectic) leads to the formation of magma supersaturated with chromite (melt C, Fig. 1) and from which only chromite can crystallize forming chromitites. The most suitable tectonic setting for this is the mantle of mid-ocean ridges.

The process of crystallization of chrome spinel occurs in chemically isolated flow channels along which melts rise in the spreading zones under the mid-ocean ridges. The concept of "flow channels" is described in [32-38]. Russian authors (for example: $[32,39,40])$ developed this concept in detail from the perspective of the question of the petrogenesis of ophiolites. As a result, the supersubduction nature of ophiolites of the Voykaro-Syninsky and Ray-Iz massifs was identified [40, 41], and a three-stage (depletion - fluid-magmatic transformation - metamorphism) scenario of the structural-material evolution of the Polar Urals ultramafites was proposed [40].

The petrogenesis of large and super-large deposits of the Kempirsay massif is considered by modern researchers as a multi-stage process [42]. At the initial stage, alumina chromites crystallized from basaltic melts formed during the depletion of peridotites. Crystallization occurred in magma chambers in the upper mantle or at the crust-mantle boundary. Then, within the massif, a subduction zone was laid, within which sedimentary rocks were metamorphosed into an eclogite facies. There was a metasomatic transformation of the depleted 

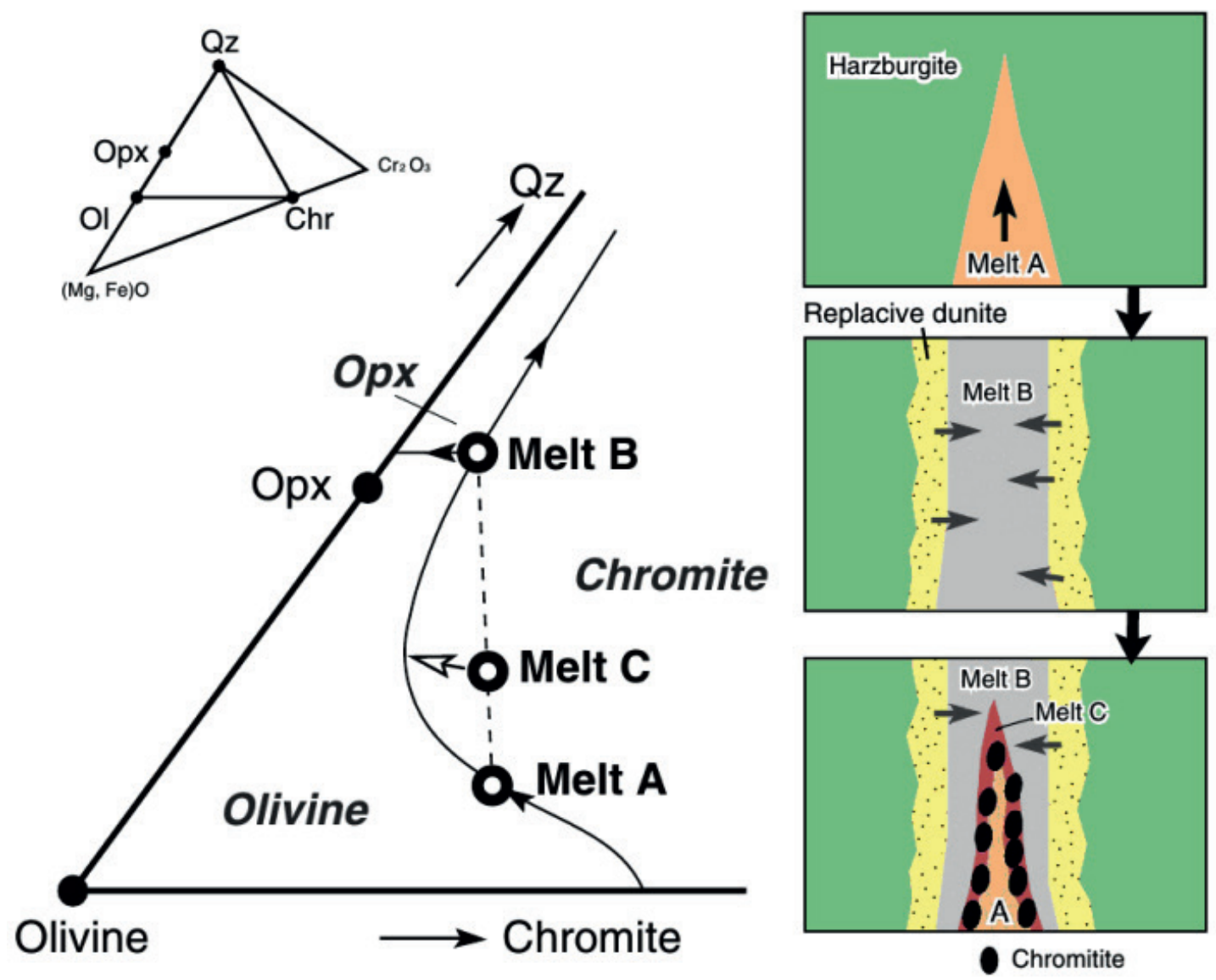

Figure 1. Petrological model of the formation of podiform chromitites in mantle harzburgites [29].

Рисунок 1. Петрологическая модель образования подиформных хромититов в мантийных гарцбургитах [29].

rocks under the action of the released fluid and repeated partial melting, which resulted in the formation of magnesian, relatively $\mathrm{SiO}_{2}$-rich water-containing melts that rose along the channels. Under the influence of these melts and the rising oxidizing fluid, the harzburgites around the channels were transformed into dunites. Then, crystallization of high-chromium chromite occurred inside these channels.

The flow channels, and, accordingly, their markers - dunite veins of the reticulate complex, have a fractal structure similar to the root system of a tree (Fig. 2) and converge in the region of the mid-ocean ridges [32]. Dunite bodies containing chrome mineralization should, according to the models of Shoji Arai and Mei-Fu Zhou, have a shape close to the vein. However, in the polar Ural massifs studied in this work, Ray-Iz and Voykaro-Syninsky, the bodies of dunites are lenticular and complex, have irregular shape, the surface of which is closed and there are no channels leading to the melt. Ore bodies are found in the dunite-harzburgite complex surrounded by a dunite rim with a thickness of $0.5-2 \mathrm{~m}$ or less. This feature is discussed in the work [43]. The authors suggest that the formation of lens-shaped and complex dunite bodies and chromitite bodies with a low-thickness dunite rim is associated with peridotite deformations during spreading. Dunite channels move and separate, acquiring a lenticular shape. At the same time, it is unclear about the way some of the dunites retains the shape of their veins. There is no explanation of variation within the same massif of compositions of ore-forming chrome spinels from aluminous to high-chromium.
According to the ideas of Christian Ballhaus [44], the formation of chromitites occurs upon physical mixing of a high pressure, more basic and low viscosity melt with a low pressure, siliceous (enriched orthopyroxene) and more viscous. In a low-pressure melt, a high-pressure one forms droplets, and at the interface between the melts, crystallization of chromite begins, which can either fill the drop, in this case nodular chromitites form, or form a border around it, which causes the formation of orbicular chromic ores.

A later article with his participation [45] suggests a different scenario. The formation of podiform chromitites rocks can occur only in tectonic environments in which the water content in the basaltic melt is high enough to isolate during decompression in mantle conditions of a water-saturated fluid phase. Such environments are supra-subduction zones. In the immiscible basalt-water system, chromite and olivine are separated. Chromite goes into a separating fluid, while olivine (and possibly other silicate phases) remains in the silicate melt. Fractionation is due to different wetting properties of the fluid and the melt with respect to the surface of silicates and oxides. The formation of chromium spinel concentrations occurs as the process of concentration of ores by flotation with the formation of fluid spinel foam.

Modern models of chromite formation proposed by Russian researchers

Since the mid-nineties of the 20th century, when performing geological surveys of the Polar Ural ultramafites, the scheme of their division proposed by Boris Vasilevich 


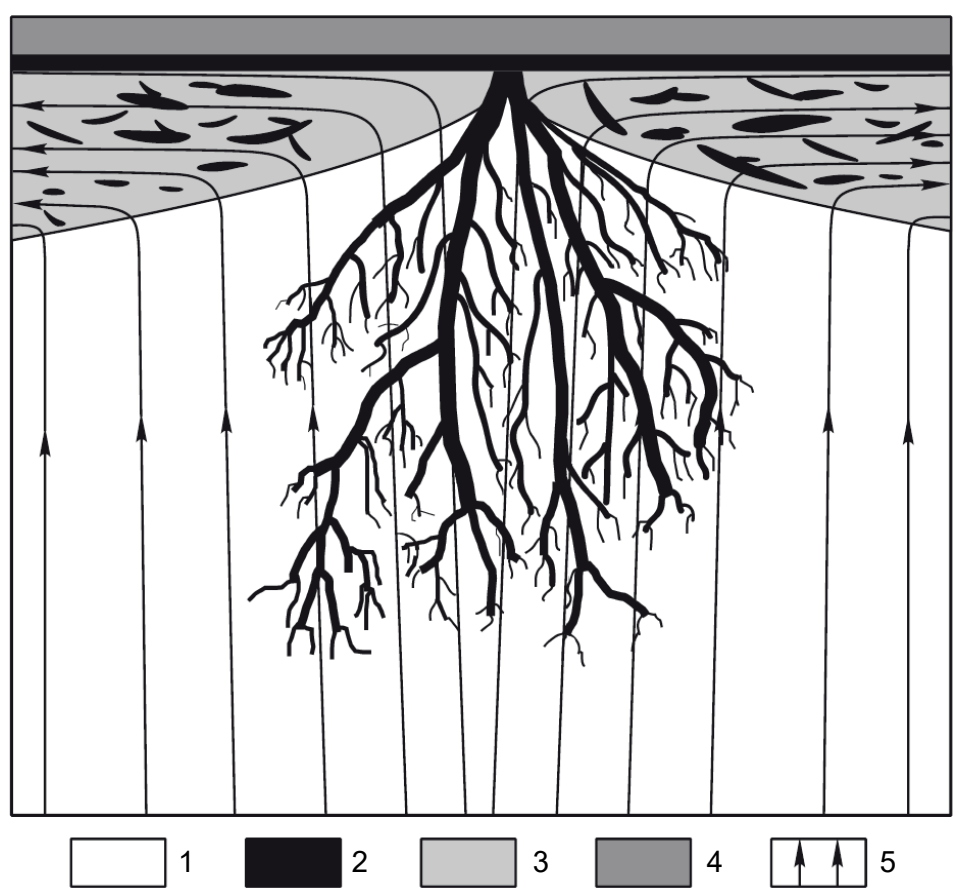

Figure 2. Schematic image of connecting network of channels of melt flow under mid-ocean ridges [32]. 1 - asthenosphere; 2 - dunites; 3 - lithosphere; 4 - oceanic crust; 5 - direction of the mantle matter flow.

Рисунок 2. Схематическое изображение соединяющейся сети каналов течения расплавов под СОХ [32]: 1 - астеносфрера; 2 - дуниты; 3 - литосфера; 4 - океаническая кора; 5 - направление течения мантийного вещества.

Perevozchikov has been widely used [46]. It provides for segregation of 4 structural-material complexes: lherzolite, harzburgite, dunite-harzburgite, verlite-dunite. Aluminous-type chromitites are localized in the harzburgite complex, high chromium-type - in the dunite-harzburgite complex, and ferruginous-type - in the verlite-dunite complex. The formation of chromium ores of alumina type, according to B. V. Perevozchikov, is associated with the stage of brittle-plastic deformation of harzburgites, which began after separation of the basaltic melt from the mantle diapir in the mid-ocean ridges zone. The decrease in pressure in the zones of plastic-shear deformations was the reason for the local partial melting of harzburgites and the appearance of ore-silicate melts. After the removal of melts in the zones of cleavage-shear deformations, a refractory residue remained - restite of the dunite composition, which recorded the spatial distribution of the deformation zones and their sizes. The formation of chromium ores of the alumina type is genetically associated with the harzburgite complex. The transfer and localization of ore melts occurred along the zones of plastic-shear deformations. Additional depletion of rocks of the harzburgite complex occurring within the supersubduction mantle wedge of island arcs leads to the formation of a dunite-harzburgite complex. As in the previous case, the conditions for the partial smelting of mafic and chromitite melts and the formation of a refractory residue in the deformation zones - restite of the dunite composition are due to a local decrease in pressure in the deformation zones.

Another major researcher of the Polar Ural ophiolites and chromitites, Alexander Borisovich Makeev et al. [47] proposed a model according to which chromitites are the products of a "large-scale regional metasomatism". During this process, a concentric geological and mineralogical zonality arises, which is expressed in a regular change from the periphery to the cen- ter of the dunite component, the ratio and chemical composition of the rock-forming minerals of ultrabasites and their physical properties. According to the authors, the ore source is enstatite of the first generation. When the mantle diapir rises under varying P-T-conditions, the mineral becomes unstable and recrystallizes with the formation of enstatite, diopside and chrome spinel. The ore substance is carried by the fluid to weakened areas where chromitites are formed.

According to the data of Igor Stepanovich Chashchukhin [48], the formation of chromium deposits in dunite-harzburgite-lherzolite ("alpine-type") complexes is inextricably linked with the history of the formation of ultramafic rocks, with the stages of the conversion of the primary silicate form of chromium to oxide and its subsequent concentration. The evolution of alpinotypic ultramafic rocks takes place in 4 stages: (1) magmatic depletion of upper mantle material, (2) concentration of ore material and its redeposition by ascending flows of hot reduced fluids, (3) synkinematic metamorphic differentiation of magmatic depletion products, (4) reaction interaction of ultramafic and gabbroids. The author identifies three genetic types of chromium ores. The first is orthomagmatic, which includes, for example, low-grade impregnated and rare impregnated chromium ores from the Geophysicheskoe XII deposit (Kempirsaysky massif). The second is lateral secretion, represented by rich chromium ores formed in a fluid-saturated system. Upward, recomposed asthenospheric fluids re-settle chromium from rocks of the underlying dunite-chromite series. This type of mineralization is referred to by author as lateral-secretion. The third type of mineralization is associated with the formation of post-restite metasomatic dunites and is called metasomatic. In addition to ultramafites, the chromite of orthomagmatic or lateral secretion types can be a substrate for the formation of ores of this type. 
An alternative model is proposed by the researcher from the Institute of Geology of the Ufa Scientific Center Dmitry Evgenievich Savelyev [49]. Features of textures and structures of ultramafic rocks suggest that the rocks underwent a plastic flow, which, according to the author, was one of the main factors of petrogenesis and ore formation. The stratification (or rheomorphic differentiation) of the mantle material, accompanied, in particular, by the formation of chromite bodies, occurred during solid-phase redistribution of minerals in the rocks being a dispersion system. The main factors determining the separation of mineral phases were: particle size, density and elastic modulus.

Chromite formation model during rheomorphic differentiation proposed by D. E. Savel'ev, resembles the model of Viktor Yur'evich Alimov [50], but they differ fundamentally from each other. According to V. Yu. Alimov, at the stage of the emergence of linear zones of high-temperature plastic flow in ultrabasites, the translational mechanisms of plastic deformation are replaced by shear mechanisms with rotational modes. At the same time, stresses of a contact nature (SCN) appear at the contact sites of minerals and larger structures. Under the action of SCN, a spatial differentiation of the substance takes place: minerals with a maximum value of Young's modulus are pulled together at strain maximums at different rates. Due to this, chromites and host rocks of the dunite-harzburgite complex are formed. At the contact sites, ultrahigh pressures of tens GPa are developed.

According to the ideas of Anastasia Yur'evna Borisova [51], the crystallization of chromite from Oman occurred from a hybrid melt, a product of assimilation of deserpentinized peridotitic substance at basalts of mid-ocean ridges at the level of the Moho border. Chromium spinel crystals accumulate under the influence of gravity forming ore bodies.

Modern works of the famous researcher of the Polar Ural ophiolites Galina Nikolaevna Savel'eva are aimed at the reconstruction of chromite formation processes. As a result of studying the chemical zoning of enstatite grains from the harzburgites of the Voykaro-Syninsky and Kempirsaysky massifs and lerzolites of the Syum-Keu massif, it was identified [39, 52] that high-temperature deformation and recrystallization of ultramafic rocks leads to a syndeformational migration of $\mathrm{Cr}$, $\mathrm{Al}, \mathrm{Fe}$ from silicate to the oxide phase. In the process of ore formation, the components necessary for the formation of chromitites have transferred both thanks to the migration of $\mathrm{Cr}, \mathrm{Al}$, Fe from rock-forming silicates, and from passing melts as well. The heat influx necessary for high-temperature deformation and recrystallization of rocks is provided by melts/fluids migration through peridotites. The same melts were responsible for the formation of dunites.

The data on the ontogeny of ore-forming chromium spinels presented in [53] show that they are formed together with serpentine, chlorite, phlogopite, and chrome diopside and contain fluid and structurally weakly ordered carbon inclusions. This, according to the authors, indicates the pneumatolytic and hydrothermal genesis of the chrome-platinum ores of the Kondersky massif, as well as similar chromites of the Platinum-bearing belt of the Urals.

According to the ideas of Nadezhda Vladimirovna Vakhrusheva [54], the Ray-Iz chromium ores were formed as a result of fluid mining of ultramafic rocks and metamorphic differentiation (local metasomatism), which led to the formation of metaultramafites, chromic ores, and plagioclase mobilizate in the stress relaxation zones. The high-chromium spinel mineralization of the Tsentranoye and Zapadnoye deposits, as well as the ore occurrences of the South-West and Engayskoye ore fields of the Ray-Iz massif (Polar Urals), is localized in the rocks of the metamorphosed dunite-harzburgite complex, which are represented by the so-called "secondary harzburgites"/metaulthramafites - amphibole enstatite-olivine rocks and pegmatoid dunites. Metamorphites containing chromium mineralization are markedly depleted in aluminum, calcium, and titanium at the same silica content (normative pyroxene), compared with dunites and harzburgites that underwent only loop serpentinization and are preserved in the northeastern and eastern parts of the massif.

Findings of ultra-high pressure minerals in chromitites

The discovery of ultrahigh pressure minerals (UHP) in chromitites and ophiolites of the massifs of Tibet (Luobusa and others), the Tien Shan (Sartokhai), the Urals (Tsentralnoye, the Ray-Iz massif) and other regions forced researchers to look for other approaches to their formation.

According to the ideas of Jingsui Yang and co-authors [55], the appearance of diamonds in ophiolites and chromitites is associated with their complex tectonic history. Mantle convection is the reason for the prolonged recycling of the oceanic lithosphere with the rise under the spreading ridges and downwarping in subduction zones. Subduction and recycling transport peridotites formed in the upper mantle, with accessory grains of chrome spinel and already formed chromitite bodies together with crustal material to the transition zone. In the transition zone, partial peridotite melting occurs, spinel undergoes a phase transition, forming a phase with the structure of calcium ferrite, the minerals mix with strongly reduced phases, which could also form at great depths, in particular diamond. Partially molten peridotite becomes less dense and rises to the level of the lithospheric mantle. Most mantle peridotites that reach the lithospheric mantle return back in the process of subduction, but some can be captured in the mantle wedge above the subduction zone, where they are partially melted and worked out by arc tholeiitic and boninite magmas formed inside the mantle wedge. These migrating melts and fluids redistribute, chemically alter, and re-deposit chrome spinel grains into podiform chromitite bodies with a typical high-chromium ore mineral composition.

A close model was proposed by Shoji Arai [56]. According to it, UHP chromitites are formed due to the usual "low pressure" ones. The latter are submerged to the depths of the transition zone under the influence of mantle convection (it is also responsible for their subsequent rise), while the carbon-rich fluid inclusions contained in chromites are converted into diamonds.

Both considered models do not explain how the UHP phases, in particular, diamond, are preserved when ultramafic rocks rise (lower $\mathrm{P}$ ), and when they interact with melts and oxidizing [57] fluids under suprasubduction conditions; this process is part of the evolution of UHP -ultramafic rocks by Young.

Christian Ballhaus et al. [58] are skeptical of the possibility of the formation of diamonds and restored mineral phases under mantle conditions. They offer a more realistic, in their opinion, version. From their point of view, the formation of 
these minerals occurs when lightning enters the outcrops of ultrabasic rocks. They argue their position with the results of an experiment on the generation of an electric arc with a current strength of $9.9 \mathrm{kV} 30 \mathrm{kA}$ for $120 \mathrm{~ms}$ in a channel drilled in a basalt sample. As a result, in the area of contact of the arc with basalt, paragenesis of minerals formed, including moissanite and amorphous carbon.

In recent years, a new direction in the research of chromitites has been outlined - the study of processes and mechanisms of their deformation and the accompanying chemical transformations of ore-forming minerals. In [59], metamorphosed chromitites of the Golyama-Kamenyane massif (Bulgaria) were studied. The authors show the relationship between the deformation history and the chemical characteristics of chromite. Stresses lead to heterogeneous nucleation and rotation of chromium spinel subgrains, under the influence of which a deformation chemical transformation of the mineral occurs with the formation of zoning in large grains with a decrease in $\mathrm{Cr}$ content, $\mathrm{Al}, \mathrm{Mg}$ and an increase in the degree of iron oxidation to the edge of the grain. The grains formed during recrystallization are chemically homogeneous and have the composition of the rim of large grains. The deformation stage is associated with spinel metamorphism occurring under oxidizing conditions. In addition, in spinel grains, the kinetic redistribution of chemical elements under the influence of directed stress, established in [60], is observed, which are widespread in plastically deformed ultramafites and chromitites.

\section{Conclusion}

Intensive geological research of ultrabasic chromite-bearing massifs and chromitites has been conducted for more than a century. Most of the models for the formation of chromium ores proposed by researchers during this time are based on the assumption of crystallization of ore-forming chromic spinel from magmatic melt. The ideas about the evolution of the earth's crust, the origin and genetic types of ultrabasic massifs changed from time to time. At the same time, the "magmatic" model of chromite formation was adapted and integrated by researchers into new models of education and transformation of ultramafites.

In addition, a large amount of evidence has been accumulated over such a long period of time, which calls into question the possibility of the formation of chromium ores in this way. These include, for example:

- conclusion about the tectonic control of the chromic mineralization of the Tsentralnoye deposit [24, etc.], which cannot be explained in any of the currently popular ore formation models;

- regular arrangement of the manifestations of chromium and aluminous chromitites in the metamorphic zonality of the Voikar-Syninsky massif [54];

- significant role of fluids in the formation of chromium ores $[48,53$, etc.].

This determines the importance of exploratory research in the field of studying the conditions for the formation of chromium ores and the increased interest of researchers in this topic.

The work was performed within state assignment of the Zavaritsky Institute of Geology and Geochemistry of the Ural Branch of the Russian Academy of Sciences, no. AAAA-A18-118052590032-6.

\section{REFERENCES}

1. Arzruni A. 1882, Sur quelques minéraux des gîtes de chromite du district de Syssertsk, Oural. Bulletin de la Société minéralogique de France, vol. 5, pp. 94-97. 2. Groddeck A. V. 1879, Die Lehre von den Lagerstätten der Erze. Ein Zweig Der Geologie. Leipzig, 351 s.

3. Vogt J. H. L. 1894, Beiträge zur genetischen Classification der durch magmatische Differentiationsprocesse und der durch Pneumatolyse entstandenen Erzvorkommen. Zeitschrift für Praktische Geologie, vol. 2, s. 381-399.

4. Lindgren W. 1933, Mineral Deposits. 4th ed. N. Y.: McGraw-Hill, 930 p.

5. Sperr J., Lindgren V., Fogt I. 1933, On ore magma. Moscow; no.vosibirsk; Leningrad, 148 p.

6. Bowen N. L. 1934, Evolyutsiya izverzhennykh porod [Igneous rock evolution]. Moscow, 324 p.

7. Karpinsky A. P. 1926, On the probable origin of the native deposits of platinum of the Ural type. I. Izvestiya AN SSSR [Bulletin of the Academy of Sciences of the USSR], VI ser., vol. 20, no. 1-2, pp. 133-158. (In Russ.)

8. Betekhtin A. G. 1937, Shordzhinskiy khromitonosnyy peridotitovyy massiv (v Zakavkaz'ye) i genezis mestorozhdeniy khromistogo zheleznyaka voobshche [Shordzhinsky chromite-bearing peridotite massif (in Transcaucasia) and the genesis of chromium iron deposits in general]. Chromites of the USSR. Moscow, vol. 1, pp. 7-156.

9. Sokolov G. A. 1948, Khromity Urala, ikh sostav, usloviya kristallizatsii i zakonomernosti rasprostraneniya [Ural chromites, their composition, crystallization conditions, and distribution patterns]. Moscow, $128 \mathrm{p}$.

10. Sampson E. 1931, Varieties of Chromite Deposits. Economic geology, vol. 26, pp. 833-839.

11. Ross C. S. 1929, Is chromite always a magmatic segregation? Economic geology, vol. 24, pp. 641-645.

12. Ross C. S. 1931, The origin of chromite. Economic geology, vol. 26, pp. 540-545.

13. Keep F. E. 1930, Origin of chromite. Economic geology, vol. 25, pp. 219-221.

14. Wells F. G., Cater F. W. Jr., Rynearson G. A. 1946, Geological investigations of chromite in California. Part I. Klamath Mountains. Ch. 1. Chromite deposits of Del no.rte County, California. San Francisco: California Department of Natural Resources, Division of Mines, vol. 134, 76 p. 15. Petraschek W. 1957, Die genetische Typen des Chromlagerstätten und ihre Aufsuchung. Erzmetall, bd. 10, h. 6, s. $1013-1024$.

16. Förster I. F., Grafenauer S. 1958, Diskussion zur Arbeit von Krause "Erzmikroskopische Untersuchungen an türkischen Chromiten". Neues Jahrbuch für Mineralogie. Abhandlungen, vol. 92, pp. 171-183.

17. Pavlov N. V., Kravchenko G. G., Chuprynina I. I. 1968, Khromity Kempirsayskogo plutona [Chromites of the Kempirsay pluton]. Moscow, 178 p. 18. Moskaleva S. V. 1974, Giperbazity i ikh khromitonosnost' [Hyperbasites and their chromite content], $279 \mathrm{p}$.

19. Thayer T. P. 1964, Principal features and origin of podiform chromite deposits, and some observations on the Guleman-Soridag district, Turkey. Economic geology, vol. 59, pp. 1497-1524. https://doi.org/10.2113/gsecongeo.59.8.1497

20. Ivanov S. N. 1973, Metallogeniya na novoy geotektonicheskoy osnove. Metallogeniya i novaya global'naya tektonika [Metallogenia on a new geotectonic basis. Metallogenia and new global tectonics], pp. 11-15.

21. Yarosh P. Ya. 1980, On the primary source of chromium in dunites and the nature of accessory chromite. Zapiski RMO [Proceedings of the Russian Mineralogical Society], pp. 98-105. (In Russ.)

22. Yarosh P. Ya., Tsaritsyn E. P. 1978, Priznaki perekristallizatsii v olivinakh iz giperbazitov. Zakonomernosti razmeshcheniya poleznykh iskopayemykh [Signs of recrystallization in olivines from hyperbasites. Patterns of the distribution of minerals]. Moscow, pp. 223-230.

23. Varlakov A. S. 1978, Petrografiya, petrokhimiya, geokhimiya giperbazitov Orenburgskogo Urala [Petrography, petrochemistry, geochemistry of hyperbasites of the Orenburg Urals]. Moscow, $240 \mathrm{p}$.

24. Ovechkin A. M., Ovechkin I. A. 2010, Report with the calculation of reserves on the results of exploration on the flanks and deep horizons of the chromite deposit Tsentralnoye for 2004-2009, Kharp. 234 p. 
25. Alimov V. Yu., Vakhrusheva N. V. 1984, Kavitatsiya kak vozmozhnyy mekhanizm formirovaniya khromitovykh mestorozhdeniy [Cavitation as a possible mechanism for the formation of chromite deposits]. Yearbook-1983 of the Institute of Geology and Geochemistry, Ufa Scientific Center of the USSR Academy of Sciences. Sverdlovsk, pp. 140-143.

26. Cassard D., Nicolas A., Rabinovitch M., Moutte J., Leblanc M., Prinzhofer A. 1981, Structural classification of chromite pods in southern New Caledonia. Economic geology, vol. 76, pp. 805-831. https://doi.org/10.2113/gsecongeo.76.4.805

27. Lago B. L., Rabinowicz M., Nicolas A. 1982, Podiform chromite ore bodies: a genetic model. Journal of Petrology, vol. 23, pp. $103-125$.

28. Leblanc M., Ceuleneer G. 1991, Chromite crystallization in a multicellular magma flow: evidence from a chromitite dike in the Oman ophiolite. Lithos, vol. 27, pp. 231-257. https://doi.org/10.1016/0024-4937(91)90002-3

29. Arai S., Abe N. 1995, Reaction of orthopyroxene in peridotite xenoliths with alkali basalt melt and its implication for genesis of alpine-type chromitite. American Mineralogist, vol. 80, pp. 1041-1047. https://doi.org/10.2138/am-1995-9-1020

30. Zhou M.-F., Robinson P. T., Bai W.-J. 1994, Formation of podiform chromitites by melt/rock interaction in the upper mantle. Mineralium Deposita, vol. 29, pp. 98-101.

31. Irvine T. N. 1977, Origin of chromitite layers in the Muskox intrusion and other stratiform intrusions: a new interpretation. Geology, vol. 5, pp. 273-277. https://doi.org/10.1130/0091-7613(1977)5<273:OOCLIT>2.0.CO;2

32. Batanova V. G., Savelyeva G. N. 2009, Migration of melts in the mantle under spreading zones and the formation of substitution dunites: a review of the problem. Geologiya i geofizika [Geology and Geophysics], vol. 50, no. 9, pp. 992-1012. (In Russ.)

33. Hart S. R. 1993, Equilibration during mantle melting: a fractal tree model. Proceedings of the National Academy of Sciences USA, vol. 90, pp. 11914-11918. https://doi.org/10.1073/pnas.90.24.11914

34. Kelemen P. B., Dick H. J. B. 1995, Focused melt flow and localized deformation in the upper mantle: juxtaposition of replacive dunite and ductile shear zones in the Josephine peridotite, SW Oregon. Journal of Geophysical Research, vol. 100, no. B1, pp. 423-438. https://doi.org/10.1029/94JB02063 35. Nicolas A. A. 1986, A melt extraction model based on structural studies in mantle peridotites. Journal of Petrology, vol. 27, no. 4, pp. 999-1022. https://doi.org/10.1093/petrology/27.4.999

36. Nicolas A. A. 1990, Melt extraction from mantle peridotites: hydrofracturing and porous flow, with consequences for oceanic ridge activity. Magma transport and storage. N. Y., Wiley, pp. 159-174.

37. Spiegelman M., Kenyon P. 1992, The requirements for chemical disequilibrium during magma migration. Earth and Planetary Science Letters, vol. 109, no. 3-4, pp. 611-620. https://doi.org/10.1016/0012-821X(92)90119-G

38. Suhr G., Hellebrand E., Snow J. E., Seck H. A., Hofmann A. W. 2003, Significance of large, refractory dunite bodies in the upper mantle of the Bay of Islands Ophiolite. Geochemistry, Geophysics, Geosystems, vol. 4, no. 3, 8605. https://doi.org/10.1029/2001GC000277

39. Savelyeva G. N., Batanova V. G., Sobolev A. V. 2016, Solid-state decomposition of pyroxene-chrome spinel in mantle lerzolites of the SyumKeu massif. Geologiya i geofizika [Geology and geophysics], vol. 57, no. 10, pp. 1808-1827. (In Russ.)

40. Shmelev V. R. 2011, Mantle ultrabasites of ophiolite complexes of the Polar Urals: petrogenesis and formation conditions. Petrologiya [Petrology], vol. 19, no. 6, pp. 649-672. (In Russ.)

41. Belousov I. A., Batanova V. G., Savel'yeva G. N., Sobolev A. V. 2009, Evidence of the supersubduction nature of mantle rocks of the VoikaroSyninsky ophiolite massif, Polar Ural. Doklady Akademii nauk [Doklady Earth Sciences], vol. 429, no. 2, pp. 238-243. (In Russ.)

42. Melcher F., Grum W., Simon G., Thalhammer T. V., Stumpfl E. F. 1997, Petrogenesis of the ophiolitic giant chromite deposits of Kempirsai, Kazakhstan: a study of solid and fluid inclusions in chromite. Journal of Petrology, vol. 38, pp. 1419-1458. https://doi.org/10.1093/petrology/38.10.1419 43. González-Jiménez J. M., Griffin W. L., Proenza J. A., Gervilla F., O’Reilly S. Y., Akbulut M., Pearson N. J., Arai S. 2014, Chromitites in ophiolites: How, where, when, why? Part II. The crystallization of chromitites. Lithos, vol. 189, pp. 140-158. https://doi.org/10.1016/j.lithos.2013.09.008 44. Ballhaus C. 1998, Origin of the podiform chromite deposits by magma mingling. Earth and Planetary Science Letters, vol. 156, issues 3-4, pp. 185-193. https://doi.org/10.1016/S0012-821X(98)00005-3

45. Matveev S., Ballhaus C. 2002, Role of water in the origin of podiform chromitite deposits. Earth and Planetary Science Letters, vol. 203, pp. 235-243. https://doi.org/10.1016/S0012-821X(02)00860-9

46. Perevozchikov B. V. 1998, Osobennosti izucheniya khromitonosnosti al'pinotipnykh giperbazitov [Features of the study of chromite content of alpinotype hyperbasites]. Geology, methods of prospecting, exploration and evaluation of deposits of solid minerals. Review. Moscow, issue 3 , $46 \mathrm{p}$. 47. Makeev A. B., Bryanchaninova N. I. 1999, Topomineralogiya ul'trabazitov Polyarnogo Urala [Topomineralogy of ultrabasites of the Polar Urals]. Saint-Petersburg, $198 \mathrm{p}$

48. Chashchukhin I. S., Voteakov S. L., Shchapova Y. L. 2007, YAGR kristallokhimiya khromshpineli i oksitermobarometriya ul'tramafitov skladchatykh oblastey [Moessbauer crystal chemistry of chromspinel and oxythermobarometry of ultramafites of folded areas]. Ekaterinburg, $345 \mathrm{p}$. 49. Savel'yev D. E., Fedoseev V. B. 2014, Plastic flow and rheomorphic differentiation of substance in mantle ultramafites. Vestnik Permskogo universiteta [Vestnik of Perm University], no. 4, pp. 22-41. (In Russ.)

50. Alimov V. Yu. 2008, Deformatsionnyy mekhanizm formirovaniya khromitovogo orudeneniya $v$ al'pinotipnykh giperbazitakh [Deformation mechanism of the formation of chromite mineralization in alpinotypic hyperbasites]. Ore genesis. Proceedings of the international conference. Miass, pp. 4-7.

51. Borisova A. Y., Ceuleneer G., Kamenetsky V. S., Arai S., Béjina F., Abily B., Bindeman I. N., Polvé M., de Parseval Ph., Aigouy T., Pokrovski G. S. 2012, A new view on the petrogenesis of the Oman ophiolite chromitites from microanalyses of chromite-hosted inclusions. Journal of Petrology, vol. 53, pp. 2411-2440. https://doi.org/10.1093/petrology/egs054

52. Savelyeva G. N., Batanova V. G., Kuz'min D. V., Sobolev A. V. 2015, Composition of minerals of mantle peridotites as a reflection of oreforming processes in the mantle (using ophiolites of the Voikaro-Sinyinsky and Kempirsaisky massifs as an example). Litologiya $i$ poleznye iskopayemye [Lithology and Mineral Resources], no. 1, pp. 87-98. (In Russ.)

53. Pushkarev E. V., Kamenetsky V. S., Morozova A.V., Khiller V. V., Glavatskikh S. P., Rodemann T. 2015, Ontogeny of ore chrome spinels and composition of inclusions as indicators of pneumolithic-hydrothermal formation of platinum-bearing chromite of the Konder massif (Aldan shield). Geologiya rudnykh mestorozhdeniy [Geology of Ore Deposits], vol. 57, no. 5, pp. 394-423. (In Russ.)

54. Vakhrusheva N. V. 1996, Metamorfizm khromitonosnykh giperbazitov Polyarnogo Urala [Metamorphism of chromite-bearing hyperbasites of the Polar Urals], PhD thesis. Ekaterinburg, $24 \mathrm{p}$.

55. Yang J., Meng A., Xu X., Robinson P. T., Dilek Y., Makeyev A. B., Wirth R., Wiedenbeck M., Griffin W. L., Cliff J. 2015, Diamonds, native elements and metal alloys from chromitites of the Ray-Iz ophiolite of the Polar Urals. Gondwana Research, vol. 27, pp. $459-485$.

https://doi.org/10.1016/j.gr.2014.07.004

56. Arai S., Miura M. 2016, Formation and modification of chromitites in the mantle. Lithos, vol. 264, pp. 277-295. http://dx.doi.org/10.1016/j.lithos.2016.08.039 57. Parkinson I. J., Arculus R. J. 1999, The redox state of subduction zones: insights from arc-peridotites. Chemical Geology, vol. 160, issue 4, pp. 409-423. https://doi.org/10.1016/S0009-2541(99)00110-2

58. Ballhaus C., Wirth R., Fonseca R. O. C., Blanchard H., Pröll W., BragagniA., NagelT., SchreiberA., Dittrich S., Thome V., Hezel D. C., Below R., Cieszynski H. 2017, Ultra-high pressure and ultra-reduced minerals in ophiolites may form by lightning strikes. Geochemical Perspectives Letters, vol. 5, pp. 42-46. http://dx.doi.org/10.7185/geochemlet.1744

59. Satsukawa T., Piazolo S., González-Jiménez J. M., Colás V., Griffin W. L., O’Reilly S. Y., Gervilla F., Fanlo I., Kerestedjian T. N. 2015, Fluid-present deformation aids chemical modification of chromite: insights from chromites from Golyamo Kamenyane, SE Bulgaria. Lithos, vol. 228, pp. 78-89. 60. Ozawa K. 1989, Stress-induced Al-Cr zoning of spinel in deformed peridotites. Nature, vol. 338, pp. 141-144. https://doi.org/10.1038/338141a0 


\title{
Генезис подисрормных хромититов - обзор моделей
}

\author{
Павел Борисович ШИРЯЕВ ${ }^{1 *}$, \\ Надежда Владимировна ВАХРУШЕВА ${ }^{1,2^{* *}}$
}

${ }^{1}$ Институт геологии и геохимии им. А. Н. Заварицкого УрО РАН, Россия, Екатеринбург

2Уральский государственный горный университет, Россия, Екатеринбург

Аннотация

Ажтуальность paботьь. Исследования, направленные на выяснение генезиса хромовых руд в альпинотипных гипербазитах ведутся учеными - геологами, петрологами и геохимиками всего мира уже более века. Тем не менее вопрос об их происхождении по сей день остается дискуссионным.

Цель работь состоит в том, чтобы выделить основные этапы развития научных представлений о генезисе хромового оруденения в альпинотипных гипербазитах; представить и обобщить главные, наиболее значимые и новаторские научные идеи российских и зарубежных специалистов, которые занимались этим вопросом.

Pезультаты. Прослежена эволюция научных взглядов на генезис хромового оруденения со второй половины IX в. и до наших дней в России и за рубежом; выделены ее основные этапы. На протяжении всего этого периода доминировали представления, так или иначе связывающие образование концентраций рудообразующего шпинелида с его кристаллизацией из магматического расплава. Крупные открытия в науках о земле - появление тектоники плит, обнаружение UHP-минералов в хромитоносных ультрабазитах и др. активизировали научный поиск и привели к появлению альтернативных моделей, рассматривающих хромититы как продукты метасоматоза или метаморфизма ультрамафитов. Особое внимание в работе уделено результатам исследований отечественных специалистов, научный вклад которых в развитие представлений о генезисе хромовых руд весьма велик и в то же время, с нашей точки зрения, недооценен. Работа предназначена для геологов, петрологов и специалистов по геологии рудных месторождений, занимающихся ультрамафитами, хромовыми рудами, а также офиолитовыми комплексами в целом.

Ключевые слова: хромититы, альпинотипные ультрамафиты, офиолиты, модели образования, генезис, обзор исследований.

Работа выполнена при поддержке государственного задания ИГГ УрО РАН (регистрационный № AAAA-A18-118052590032-6).

\section{ЛИТЕРАТУРА}

1. Arzruni A. Sur quelques minéraux des gîtes de chromite du district de Syssertsk, Oural // Bulletin de la Société minéralogique de France. 1882. Vol. 5. P. 94-97.

2. Groddeck A. V. Die Lehre von den Lagerstätten der Erze. Ein Zweig Der Geologie. Leipzig, 1879. 351 s.

3. Vogt J. H. L. Beiträge zur genetischen Classification der durch magmatische Differentiationsprocesse und der durch Pneumatolyse entstandenen Erzvorkommen // Zeitschrift für Praktische Geologie. 1894. Vol. 2. S. 381-399.

4. Lindgren W. Mineral Deposits. 4th ed. N. Y.: McGraw-Hill, 1933. 930 p.

5. Сперр Дж., Линдгрен В., Фогт И. О рудной магме. М.; Новосибирск; Л.: Гос. науч.-техн. горно-геолого-нефт. изд-во, 1933.148 с.

6. Боуэн Н. Л. Эволюция изверженных пород. М.: ОНТИ, 1934. 324 с.

7. Карпинский А. П. О вероятном происхождении коренных месторождений платины уральского типа. I // Изв. АН СССР. 1926. VI сер. T. 20, № 1-2. С. 133-158.

8. Бетехтин А. Г. Шорджинский хромитоносный перидотитовый массив (в Закавказье) и генезис месторождений хромистого железняка вообще // Хромиты СССР. М.; Л.: Изд-во АН СССР, 1937. Т. 1. С. 7-156.

9. Соколов Г. А. Хромиты Урала, их состав, условия кристаллизации и закономерности распространения. М.: Изд-во АН СССР, 1948. 128 с.

10. Sampson E. Varieties of Chromite Deposits // Economic geology. 1931. Vol. 26. P. 833-839.

11. Ross C. S. Is chromite always a magmatic segregation? // Economic geology. 1929. Vol. 24. P. 641-645.

12. Ross C. S. The origin of chromite // Economic geology. 1931. Vol. 26. P. 540-545.

13. Keep F. E. Origin of chromite // Economic geology. 1930. Vol. 25. P. 219-221.

14. Wells F. G., Cater F. W. Jr., Rynearson G. A. Geological investigations of chromite in California. Part I. Klamath Mountains. Ch. 1. Chromite deposits of Del no.rte County, California. San Francisco: California Department of Natural Resources, Division of Mines. 1946. Vol. 134. 76 p.

15. Petraschek W. Die genetischen Typen der Chromerzlagerstätten und ihre Aufsuchung // Erzmetall. 1957. Bd. 10. H. 6. S. $1013-1024$.

16. Förster I. F., Grafenauer S. Diskussion zur Arbeit von Krause "Erzmikroskopische Untersuchungen an türkischen Chromiten" // Neues Jahrbuch für Mineralogie. Abhandlungen. 1958. Vol. 92. P. 171-183.

17. Павлов Н. В., Кравченко Г. Г., Чупрынина И. И. Хромиты Кемпирсайского плутона. М.: Наука, 1968. 178 с.

18. Москалева С. В. Гипербазиты и их хромитоносность. Л.: Недра, 1974. 279 с.

19. Thayer T. P. Principal features and origin of podiform chromite deposits, and some observations on the Guleman-Soridag district, Turkey // Economic geology. 1964. Vol. 59. P. 1497-1524. https://doi.org/10.2113/gsecongeo.59.8.1497

20. Иванов С. Н. Металлогения на новой геотектонической основе // Металлогения и новая глобальная тектоника. Л.: Недра, 1973. С. 11-15. 21. Ярош П. Я. О первоисточнике хрома в дунитах и природе акцессорного хромита // Записки ВМО. 1980. № 1. С. 98-105.

22. Ярош П. Я., Царицын Е. П. Признаки перекристаллизации в оливинах из гипербазитов // Закономерности размещения полезных ископаемых. М.: Наука, 1978. С. 223-230.

\footnotetext{
\shiryayev@igg.uran.ru

https://orcid.org/0000-0002-3090-6001

"vakhruscheva@igg.uran.ru

(iD) https://orcid.org/0000-0002-2790-8401
}

28 P.B. Shiryaev, N.V. Vakhrusheva.Genesis of podiform chromitites - a review of models//Известия УГГУ. 2020. Вып. 2(58). С. 20-29. 
23. Варлаков А. С. Петрография, петрохимия, геохимия гипербазитов Оренбургского Урала. М.: Наука, 1978. 240 с.

24. Овечкин А. М., Овечкин И. А. Отчет с подсчетом запасов о результатах разведочных работ на фрлангах и глубоких горизонтах хромитового месторождения «Центральное» за 2004-2009 г. Пос. Харп: Ямалгеолфонд, 2010. 234 с.

25. Алимов В. Ю., Вахрушева Н. В. Кавитация как возможный механизм формирования хромитовых месторождений // Ежегодник-1983. Свердловск: Ин-т геологии и геохимии УНЦ АН СССР, 1984. С. 140-143.

26. Cassard D., Nicolas A., Rabinovitch M., Moutte J., Leblanc M., Prinzhofer A. Structural classification of chromite pods in southern New Caledonia // Economic geology. 1981. Vol. 76. P. 805-831. https://doi.org/10.2113/gsecongeo.76.4.805

27. Lago B. L., Rabinowicz M., Nicolas A. Podiform chromite ore bodies: a genetic model // Journal of Petrology. 1982. Vol. 23. P. 103-125.

28. Leblanc M., Ceuleneer G. Chromite crystallization in a multicellular magma flow: evidence from a chromitite dike in the Oman ophiolite // Lithos. 1991. Vol. 27. P. 231-257. https://doi.org/10.1016/0024-4937(91)90002-3

29. Arai S., Abe N. Reaction of orthopyroxene in peridotite xenoliths with alkali basalt melt and its implication for genesis of alpine-type chromitite // American Mineralogist. 1995. Vol. 80. P. 1041-1047. https://doi.org/10.2138/am-1995-9-1020

30. Zhou M.-F., Robinson P. T., Bai W.-J. Formation of podiform chromitites by melt/rock interaction in the upper mantle // Mineralium Deposita, 1994. Vol. 29. P. 98-101.

31. Irvine T. N. Origin of chromitite layers in the Muskox intrusion and other stratiform intrusions: a new interpretation // Geology. 1977. Vol. 5. P. 273-277. https://doi.org/10.1130/0091-7613(1977)5<273:OOCLIT>2.0.CO;2

32. Батанова В. Г., Савельева Г. Н. Миграция расплавов в мантии под зонами спрединга и образование дунитов замещения: обзор проблемы // Геология и геофизика. 2009. Т. 50, № 9. С. 992-1012.

33. Hart S. R. Equilibration during mantle melting: a fractal tree model // Proceedings of the National Academy of Sciences USA. 1993. Vol. 90. P. 11914-11918. https://doi.org/10.1073/pnas.90.24.11914

34. Kelemen P. B., Dick H. J. B. Focused melt flow and localized deformation in the upper mantle juxtaposition of replacive dunite and ductile shear zones in the Josephine peridotite, SW Oregon // Journal of Geophysical Research. 1995. Vol. 100, № B1. P. 423-438.

https://doi.org/10.1029/94JB02063

35. Nicolas A. A. melt extraction model based on structural studies in mantle peridotites // Journal of Petrology. 1986. Vol. 27, № 4. P. 999-1022. 36. Nicolas A. A. Melt extraction from mantle peridotites: hydrofracturing and porous flow, with consequences for oceanic ridge activity // Magma transport and storage. N. Y.: Wiley, 1990. P. 159-174.

37. Spiegelman M., Kenyon P. The requirements for chemical disequilibrium during magma migration // Earth and Planetary Science Letters. 1992. Vol. 109, № 3-4. P. 611-620. https://doi.org/10.1016/0012-821X(92)90119-G

38. Suhr G., Hellebrand E., Snow J. E., Seck H. A., Hofmann A. W. Significance of large, refractory dunite bodies in the upper mantle of the Bay of Islands Ophiolite // Geochemistry, Geophysics, Geosystems. 2003. Vol. 4, № 3. 8605. https://doi.org/10.1029/2001GC000277

39. Савельева Г. Н., Батанова В. Г., Соболев А. В. Твердофазный распад пироксен-хромшпинель в мантийных лерцолитах массива Сыум-Кеу // Геология и геофизика. 2016. Т. 57, № 10. С. 1808-1827.

40. Шмелев В. Р. Мантийные ультрабазиты офиолитовых комплексов Полярного Урала: петрогенезис и обстановка формирования // Петрология. 2011. Т. 19, № 6. С. 649-672.

41. Белоусов И. А., Батанова В. Г., Савельева Г. Н., Соболев А. В. Свидетельство надсубдукционной природы мантийных пород ВойкароСыньинского офиолитового массива, Полярный Урал // ДАН. 2009. Т. 429, № 2. С. 238-243.

42. Melcher F., Grum W., Simon G., Thalhammer T. V., Stumpfl E. F. Petrogenesis of the ophiolitic giant chromite deposits of Kempirsai, Kazakhstan: a study of solid and fluid inclusions in chromite // Journal of Petrology. 1997. Vol. 38. P. 1419-1458. https://doi.org/10.1093/petrology/38.10.1419 43. González-Jiménez J. M., Griffin W. L., Proenza J. A., Gervilla F., O’Reilly S. Y., Akbulut M., Pearson N. J., Arai S. Chromitites in ophiolites: How, where, when, why? Part II. The crystallization of chromitites // Lithos. 2014. Vol. 189. P. 140-158. https://doi.org/10.1016/j.lithos.2013.09.008 44. Ballhaus C. Origin of the podiform chromite deposits by magma mingling // Earth and Planetary Science Letters. 1998. Vol. 156. P. 185-193. https://doi.org/10.1016/S0012-821X(98)00005-3

45. Matveev S., Ballhaus C. Role of water in the origin of podiform chromitite deposits // Earth and Planetary Science Letters. 2002. Vol. 203. P. 235-243. https://doi.org/10.1016/S0012-821X(02)00860-9

46. Перевозчиков Б. В. Особенности изучения хромитоносности альпинотипных гипербазитов // Геология, методы поисков, разведки и оценки месторождений твердых полезных ископаемых: обзор. инфрорм. М.: АОЗТ «Геоинформмарк», 1998. Вып. 3. 46 с.

47. Макеев А. Б., Брянчанинова Н. И. Топоминералогия ультрабазитов Полярного Урала. СПб.: Наука, 1999. 198 с.

48. Чащухин И. С., Вотяков С. Л, Щапова Ю. Л. ЯГР кристаллохимия хромшпинели и окситермобарометрия ультрамафитов складчатых областей. Екатеринбург: Ин-т геологии и геохимии УрО РАН, 2007. 345 с.

49. Савельев Д. Е., Федосеев В. Б. Пластическое течение и реоморфическая дифференциация вещества в мантийных ультрамафитах // Вестник Пермского университета. Геология. 2014. № 4. С. 22-41.

50. Алимов В. Ю. Деформационный механизм формирования хромитового оруденения в альпинотипных гипербазитах // Рудогенез: материалы междунар. конф. Миасс: Ин-т минералогии УрО РАН, 2008. С. 4-7.

51. Borisova A. Y., Ceuleneer G., Kamenetsky V. S., Arai S., Béjina F., Abily B., Bindeman I. N., Polvé M., de Parseval Ph., Aigouy T., Pokrovski G. S. A new view on the petrogenesis of the Oman ophiolite chromitites from microanalyses of chromite-hosted inclusions // Journal of Petrology. 2012. Vol. 53. P. 2411-2440. https://doi.org/10.1093/petrology/egs 054

52. Савельева Г. Н., Батанова В. Г., Кузьмин Д. В., Соболев А. В. Состав минералов мантийных перидотитов как отражение рудообразующих процессов в мантии (на примере офиолитов Войкаро-Сыньинского и Кемпирсайского массивов) // Литология и полезные ископаемые. 2015. № 1. С. $87-98$.

53. Пушкарев Е. В., Каменецкий В. С., Морозова А. В., Хиллер В. В., Главатских С. П., Родеманн Т. Онтогения рудных хромшпинелидов и состав включений как индикаторы пневматолито-гидротермального образования платиноносных хромититов массива Кондер (Алданский щит) // Геология рудных месторождений. 2015. Т. 57, № 5. С. 394-423.

54. Вахрушева Н. В. Метаморфизм хромитоносных гипербазитов Полярного Урала: автореф. дис. ... канд. геол.-минерал. наук. Екатеринбург, 1996. 24 с.

55. Yang J., Meng A., Xu X., Robinson P. T., Dilek Y., Makeyev A.B., Wirth R., Wiedenbec M., Griffin W. L., Cliff J. Diamonds, native elements and metal alloys from chromitites of the Ray-Iz ophiolite of the Polar Urals // Gondwana Research. 2015. Vol. 27. P. 459-485. https://doi.org/10.1016/j. gr.2014.07.004

56. Arai S., Miura M. Formation and modification of chromitites in the mantle // Lithos. 2016. Vol. 264. P. 277-295. http://dx.doi.org/10.1016/j. lithos.2016.08.039

57. Parkinson I. J., Arculus R. J. The redox state of subduction zones: insights from arc-peridotites // Chemical Geology. 1999. Vol. 160. Issue 4. P. 409-423. https://doi.org/10.1016/S0009-2541(99)00110-2

58. Ballhaus C., Wirth R., Fonseca R. O. C., Blanchard H., Pröll W., Bragagni A., Nagel T., Schreiber A., Dittrich S., Thome V., Hezel D. C., Below R., Cieszynski H. Ultra-high pressure and ultra-reduced minerals in ophiolites may form by lightning strikes // Geochemical Perspectives Letters. 2017. Vol. 5. P. 42-46. http://dx.doi.org/10.7185/geochemlet.1744

59. Satsukawa T., Piazolo S., González-Jiménez J. M., Colás V., Griffin W. L., O’Reilly S. Y., Gervilla F., Fanlo I., Kerestedjian T. N. Fluid-present deformation aids chemical modification of chromite: insights from chromites from Golyamo Kamenyane, SE Bulgaria // Lithos. 2015. Vol. 228. P. 78-89. 60. Ozawa K. Stress-induced Al-Cr zoning of spinel in deformed peridotites // Nature. 1989. Vol. 338. P. 141-144. https://doi.org/10.1038/338141a0 